\title{
Effect of Moisture Regime on IW/CPE Ratio on Soil Properties, Yield and Water use Efficiency of Wheat Crop (Triticum aestivum L.)
}

\author{
Sudhir Pal ${ }^{1}$, Suresh Kumar ${ }^{1}$, Pravesh Kumar ${ }^{1}$, Anshul Singh ${ }^{2}$ \\ and Hemant Kumar Gangwar ${ }^{3}$
}
${ }^{1}$ Department of Soil Science and Agricultural Chemistry, Acharya Narendra Deva University of Agriculture and Technology, Kumarganj, Ayodhya-224 229, India
${ }^{2}$ Department of Soil Science and Agricultural Chemistry, C.S.A University of Agriculture \& Technology Kanpur, India
${ }^{3}$ Department of Agronomy, College of Agriculture, Acharya Narendra Deva University of Agriculture and Technology, Kumarganj, Ayodhya 224 229, India

*Corresponding author

\section{A B S T R A C T}

\begin{tabular}{|l|}
\hline K e y w o r d s \\
Consumptive use, \\
moisture regime, \\
root growth, soil \\
properties, wheat, \\
water use efficiency \\
\hline Article Info \\
\hline $\begin{array}{l}\text { Accepted: } \\
\text { 20 February } 2020 \\
\text { Available Online: } \\
\text { 10 March } 2020\end{array}$ \\
\hline
\end{tabular}

The field experiment was conducted at Instructional farm of A.N.D University of Agriculture and Technology, Kumarganj, Ayodhya (U.P.) during Rabi, 2016-17. The treatments was comprised with five levels of irrigation viz. CRI stage $\left(\mathrm{I}_{1}\right), 0.6 \mathrm{IW} / \mathrm{CPE}$ ratio $\left(\mathrm{I}_{2}\right), 0.8 \mathrm{IW} / \mathrm{CPE}$ ratio $\left(\mathrm{I}_{3}\right), 1.0 \mathrm{IW} / \mathrm{CPE}$ ratio $\left(\mathrm{I}_{4}\right)$, and $1.2 \mathrm{IW} / \mathrm{CPE}$ ratio $\left(\mathrm{I}_{5}\right)$ in Randomize Block Design with four replications. The results reaveled that the highest fresh and dry weight and density of root, grain and straw yield by crop were recorded with 1.0 IW/CPE ratio $\left(\mathrm{I}_{4}\right)$ moisture regime followed by $1.2 \mathrm{IW} / \mathrm{CPE}$ ratio $\left(\mathrm{I}_{5}\right)$ and minimum with CRI stage $\left(\mathrm{I}_{1}\right), 0.6 \mathrm{IW} / \mathrm{CPE}$ ratio. The maximum reduction in $\mathrm{pH}$ and $\mathrm{EC}$ and buildup in organic carbon were recorded of $\left(\mathrm{I}_{4}\right) 1.0 \mathrm{IW} / \mathrm{CPE}$ ratio (6 irrigations). The maximum moisture extraction was noticed in the upper most soil layer i.e. 0-20 cm followed by 2040 and 40-60 cm depth. Increasing levels of moisture regimes from CRI stage $\left(\mathrm{I}_{1}\right)$ to 1.2 IW/CPE ratio $\left(\mathrm{I}_{5}\right)$ increased the moisture extraction. The increment in extraction of soil moisture and consumptive use of water and reduction in water use efficiency were recorded with the increasing moisture regimes from CRI stage $\left(\mathrm{I}_{1}\right)$ to $1.2 \mathrm{IW} / \mathrm{CPE}$ ratio $\left(\mathrm{I}_{5}\right)$. The maximum water use efficiency of $\left(166.6 \mathrm{~kg} \mathrm{ha}^{-1} \mathrm{~cm}^{-1}\right)$ was obtained under moisture regime at CRI stage $\left(\mathrm{I}_{1}\right)$ followed by irrigation at $0.6 \mathrm{IW} / \mathrm{CPE}\left(\mathrm{I}_{2}\right)$. The lowest water use efficiency $\left(71.7 \mathrm{~kg} \mathrm{ha}^{-1} \mathrm{~cm}^{-1}\right)$ was recorded under moisture regime at $1.2 \mathrm{IW} / \mathrm{CPE}$ ratio $\left(\mathrm{I}_{5}\right)$.

\section{Introduction}

Wheat (Triticum aestivum L.) is one of the most important cereal crop of the world. Among the world's most important food grains, it ranks next to rice. It is eaten in various forms by more than one billion in the world. India is the second largest producer of wheat in the world. In India production was 97.44 million tons from an area of 30.73 
million hectares with productivity of 3172 tones $\mathrm{ha}^{-1}$ (Anonymous 2016-17). UP ranks first in respect of crop coverage area 9.13 million hectares and production 24.57 million tons and the productivity $2690 \mathrm{kgha}^{-1}$ (Anonymous, 2016-17). Water is a precious and scare input plays a vital role in assured crop production since it is essential for the maintenance to turgidity, absorption of nutrients and the metabolic process of the plants. Therefore, it becomes imperative to develop an optimum irrigation schedule to maintain the sufficient available soil moisture throughout the crop period for best exploitation of crop yield potential. Among the several recognized criteria of irrigation scheduling, climatologically approach is very scientific and widely accepted among the scientists and research workers throughout the world. It is well known that evapotranspiration by a full crop cover is closely associated with the evaporation from an open pan (Dastane, 1972).

Parihar et al., (1976) suggested a relatively more practical meteorological approach of IW/CPE which is a ratio between fixed amount of irrigation water (IW) and cumulative pan evaporation minus rains. This IW/CPE approach merits on account of its simplicity of operation and high water use efficiency. It is an established fact that in future, less and less of water will be available for agriculture on account of increasing water demand for domestic, industrial and other purposes. It is estimated that even after achieving the full irrigation potential, nearly $50 \%$ of the total cultivated area will remain rain fed (Vision, 2020).

Irrigation water is a major constraint for assumed crop production. Evapo-transpiration by a full crop cover is closely associated with the evaporation from an open pan. At present irrigation is very costly input so will be used very judiciously. Parihar et al., (2003) suggested a relatively more practical meteorological approach of IW/CPE, the ratio between a fixed amount of irrigation water (IW) and Cumulative Pan Evaporation, as a basis for irrigation scheduling to crops. IW/CPE approach merits special consideration on account of its simplicity of operation. IW/CPE is taken for applying water to wheat and for comparative study treatments at critical growth stages. Keeping all this in view, an attempt has been made to study the effect of irrigation scheduling based on IW/CPE ratio on soil properties, yield and water use efficiency of wheat crop.

\section{Materials and Methods}

Field experiments were conducted during the Rabi season of 2016-17 at Student's Instructional Farm, Narendra Deva university of Agriculture and Technology Narendra Nagar, Kumarganj, Ayodhya. The farm is located $42 \mathrm{~km}$ away from Faizabad city on Raibareily road at $26.47^{\circ} \mathrm{N}$ latitude and $82.12^{\circ} \mathrm{E}$ longitude and about 113 meter above the mean sea level. The experimental soil was silty loam having with $\mathrm{pH} 8.20$, EC $0.30 \mathrm{dSm}^{-}$ 1, organic carbon $4.0 \mathrm{gkg}^{-1}$, available N 187, P 17.25 and $\mathrm{K} 269 \mathrm{kgha}^{-1}$. To assess the properties of soil sample experiment, Soil $\mathrm{pH}$ and EC determined by following Chopra and Kanwar (1991). Soil organic carbon determined by Walkley and Black (1934) rapid titration procedure as outlined by Jackson (1973). Soil available nitrogen determined following Subbiah and Asija (1956).

Available phosphorus determined by Olsen et al., (1954) method and Available potassium determined by following Jackson (1973). The experiment was laid out in randomized block design with four replications. Five treatments comprised of four levels of moisture regime (a) $\mathrm{I}_{2} ; 0.6 \mathrm{IW} / \mathrm{CPE}$ ratio (b) $\mathrm{I}_{3} ; 0.8 \mathrm{IW} / \mathrm{CPE}$ ratio $(c) \mathrm{I}_{4} ; 1.0 \mathrm{IW} / \mathrm{CPE}$ ratio and (d) $\mathrm{I}_{5} ; 1.2$ 
IW/CPE ratio and (e) CRI stage $\left(\mathrm{I}_{1}\right)$. The wheat variety $\mathrm{PBW}-154$ was taken as a test crop. It was sown in $20 \mathrm{~cm}$ row to row distance on December $2^{\text {nd, }} 2016$ and harvested on April $14^{\text {th }}, 2017$. Fertilization was done by using inorganic fertilizers and half of nitrogen and full dose of phosphorus and potash were applied at the time of sowing as per treatments.

The remaining nitrogen as per treatment was top dressed after first irrigation. $\mathrm{N}, \mathrm{P}$, and $\mathrm{K}$ were applied through urea, DAP and muriate of potash, respectively. The cultural practices were followed as per recommendations. Irrigations as per treatments were applied in individual plots.

The IW/CPE ratios were calculated based on depth of irrigation water and the cumulative pan evaporation during the period. Soil moisture samples were taken from 0-20, 2040 and $40-60 \mathrm{~cm}$ soil depth at before and after each irrigation and also at sowing and harvesting of the crop. Fresh weight of sample was recorded and these soil samples were dried in an oven at $105{ }^{0} \mathrm{C}$ till the constant dry weight.

The moisture extraction was calculated on dry weight basis and entire root zone was computed. The consumptive use of water was calculated with moisture percentage on oven dry weight basis, bulk density, effective rainfall and summation of evapotranspiration. The water use efficiency was worked out by using grain produced per unit of water received which was total water applied. Root samples were taken from 0-20 and $20-40 \mathrm{~cm}$ soil depth at harvest.

The samples containing roots from different were thoroughly washed by putting on one $\mathrm{mm}$ sieve kept on moving water. The roots left were collected after measuring the fresh weight of roots these roots were air dried and kept in an oven at $65^{\circ} \mathrm{C}$ temperature till constant weight to obtain dry weight. For obtaining the root density, root volume was determined with the help of empty measuring cylinder. From the individual plot the crop of net plot area was harvested for taking observation. The final grain weight was recorded in $\mathrm{kg}$ per plot and converted into quintal per hectare.

\section{Results and Discussion}

\section{Fresh and dry weight of root}

Data pertaining to fresh and dry weight of root as influence by moisture regime have been presented in Table 1.The fresh and dry weight of roots were increased with increasing moisture regimes of wheat crop. Significant increase in fresh and dry weight of root was observed with increasing moisture regimes from CRI stage $\left(\mathrm{I}_{1}\right)$ to $1.2 \mathrm{IW} / \mathrm{CPE}$ ratios $\left(\mathrm{I}_{5}\right)$. The maximum root weight from 0 $20 \mathrm{~cm}$ layer was decreased with increasing soil depth up to $20-40 \mathrm{~cm}$.

The maximum fresh and dry weight of root (5.15 and 2.36 g plant $^{-1}$ ) at $0-20 \mathrm{~cm}$ depth was recorded with 1.0 IW/CPE $\left(\mathrm{I}_{4}\right)$ which was significantly higher with the $\mathrm{I}_{3}, \mathrm{I}_{2}, \mathrm{I}_{1}$ and statistically at par with $\mathrm{I}_{5}$. The fresh weight of root at $20-40 \mathrm{~cm}$ was significant under moisture regime IW/CPE ratio1.2 $\left(\mathrm{I}_{5}\right)$ over the rest moisture regime but dry weight of root at $20-40 \mathrm{~cm}$ was statistically at par among the moisture regimes. The highest value was recorded with moisture regime $1.0 \mathrm{IW} / \mathrm{CPE}$ ratio $\left(\mathrm{I}_{4}\right)$ and lower was recorded at CRI stage $\left(\mathrm{I}_{1}\right)$. This might be attributed due to extensively, thick and good establishment of roots under adequate moisture supply. The adequate carbohydrate supply from the top due to better growth under sufficient moisture supply possibly favored for better root growth which increased root fresh and dry weight. 


\section{Density of root}

The data regarding the root density at different soil depth at harvest presented in Table 1. In general, the root density decreased with increased soil depth from 0-20 to $20-40 \mathrm{~cm}$ with the different moisture regimes. The root density was not affected significantly under the different moisture regimes. The highest root density $\left(0.84 \mathrm{gcm}^{-3}\right)$ was recorded with the moisture regime1.0 IW/CPE $\left(\mathrm{I}_{4}\right)$ ratio followed by $1.2 \mathrm{IW} / \mathrm{CPE}$ $\left(\mathrm{I}_{5}\right)$ and minimum was recorded $0.77 \mathrm{~g} \mathrm{~cm}^{-3}$ at CRI stage in $0-20$ and $20-40 \mathrm{~cm}$ layer. The increases in root density due to increase in irrigation levels was also reported by Chaudhary and Bhatnagar (1980) and Sharma et al (1990).

\section{Grain and straw yield}

The grain and straw yield were significantly influenced by different moisture regimes presented Table 1. The highest grain and straw yield (42.67 and $56.75 \mathrm{qha}^{-1}$ ) were recorded with the levels of irrigation $\mathrm{I}_{4}(1.0$ IW/CPE ratio) which was statistically at par with $\mathrm{I}_{5}: 1.2$ IW/CPE, however, it was significantly superior over $\mathrm{I}_{2}(0.6 \mathrm{IW} / \mathrm{CPE}$ ratio), $\mathrm{I}_{3}$ (0.8 IW/CPE Ratio) and $\mathrm{I}_{1}$ (at CRI stage). Considering the progress of yield in percentage, it was $90.75 \%$ higher over the application of irrigation at CRI stage. It was due to timely and adequate supply of water at the crop growth and development stages and this did interfere with crop growth and profuse tillering continued with increasing rate at harvest. Similar result has also been reported by Rehman et al., (2000), Dangar et al., (2017) and Kumar et al., (2018).

\section{Soil Properties}

Soil $\mathrm{pH}, \mathrm{EC}$ and organic carbon as affected by different moisture regimes are presented in Table 1. It revealed that the different moisture regimes could not significantly influence the soil pH, Electrical Conductivity an Organic Carbon. However, nominal reduction in soil $\mathrm{pH}, \mathrm{EC}$ and buildup in organic carbon were observed at harvest of the crop. The range in soil $\mathrm{pH}$ and $\mathrm{EC}$ and organic carbon were 8.17 to $8.13,0.20$ to 0.29 and 4.1 to $4.8 \mathrm{~g} \mathrm{~kg}^{-1}$ respectively.

The higher reduction in $\mathrm{pH}, \mathrm{EC}$ and buildup in organic carbon was recorded under moisture regime 1.2 IW/CPE $\left(\mathrm{I}_{5}\right)$ applied as seven irrigations and minimum was recorded under moisture regime at CRI stage $\left(\mathrm{I}_{1}\right)$ where applied only one irrigation during entire growth period. These finding are supported by Bhattacharyay et al., (2008), Adejumobi et al., (2014) and Yassen et al., (2014).

\section{Moisture extraction pattern}

The data on moisture extraction pattern presented in table 2 . The maximum extraction was noticed in the upper most soil layer i.e. 0$20 \mathrm{~cm}$ followed by $20-40$ and $40-60 \mathrm{~cm}$ depth. Increasing levels of moisture regimes from at CRI stage $\left(\mathrm{I}_{1}\right)$ to $1.2 \mathrm{IW} / \mathrm{CPE}$ ratio $\left(\mathrm{I}_{5}\right)$ increased the moisture extraction in each soil layer.

However the depletion of soil moisture from the deeper layers was comparatively higher under CRI stage $\left(\mathrm{I}_{1}\right)$ and $0.6 \mathrm{IW} / \mathrm{CPE}\left(\mathrm{I}_{2}\right)$ than under $1.0\left(\mathrm{I}_{4}\right)$ and $1.2 \mathrm{IW} / \mathrm{CPE}$ ratio $\left(\mathrm{I}_{5}\right)$. The highest water supply at $1.2 \mathrm{IW} / \mathrm{CPE}$ ratio $\left(\mathrm{I}_{5}\right)$ revealed that the total depletion of moisture increased with increasing level of moisture and it was maximum under moisture regimes at $1.2 \mathrm{IW} / \mathrm{CPE}$ ratio $\left(\mathrm{I}_{5}\right)$.

The maximum depletion of $21.01 \mathrm{~cm}$ was noticed under moisture regime 1.2 IW/CPE ratio $\left(\mathrm{I}_{5}\right)$ followed by $20.20 \mathrm{~cm}$ under 1.0 IW/CPE ratio $\left(I_{4}\right)$, while minimum $16.51 \mathrm{~cm}$ recorded under at CRI stage $\left(\mathrm{I}_{1}\right)$. 
Table.1 Effect of moisture regimes on fresh and dry weight and density of root, yield and soil properties after harvest of the wheat crop

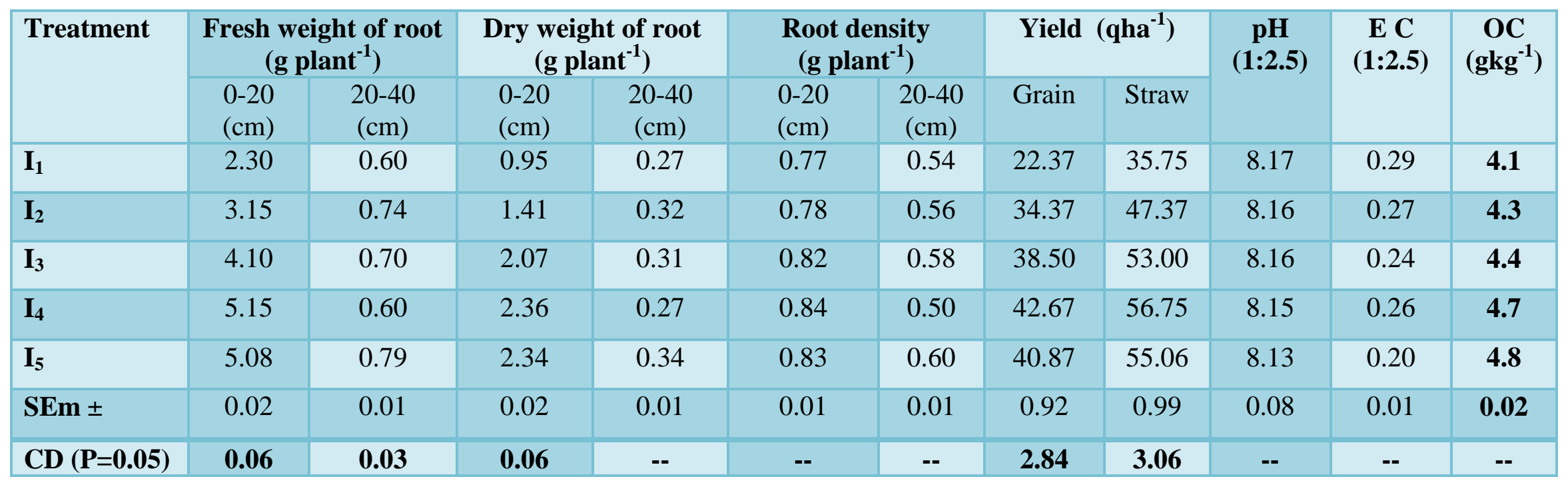

Table.2 Effect of different moisture regime on soil moisture extraction pattern, consumptive use and water use efficiency in wheat crop

\begin{tabular}{|c|c|c|c|c|c|c|}
\hline \multirow[t]{2}{*}{ Treatment } & \multicolumn{3}{|c|}{ Soil Depth (cm) } & \multirow{2}{*}{$\begin{array}{c}\text { Total } \\
\text { Extraction } \\
\quad(\mathrm{cm})\end{array}$} & \multirow{2}{*}{$\begin{array}{l}\text { Consumptive } \\
\text { use }(\mathrm{cm})\end{array}$} & \multirow{2}{*}{$\begin{array}{c}\text { Water use } \\
\text { efficiency }(\mathrm{kg} \\
\left.\mathrm{ha}^{-1} \mathrm{~mm}^{-1}\right)\end{array}$} \\
\hline & $0-20$ & $20-40$ & $40-60$ & & & \\
\hline $\mathbf{I}_{1}$ & 7.2 & 5.76 & 3.55 & 16.51 & 13.42 & 16.66 \\
\hline $\mathbf{I}_{2}$ & 8.24 & 6.36 & 3.61 & 18.21 & 41.47 & 8.28 \\
\hline $\mathbf{I}_{3}$ & 8.32 & 6.44 & 3.83 & 18.59 & 47.15 & 8.16 \\
\hline $\mathbf{I}_{4}$ & 9.20 & 6.80 & 4.20 & 20.20 & 53.72 & 7.94 \\
\hline $\mathbf{I}_{5}$ & 9.68 & 6.90 & 4.43 & 21.01 & 56.95 & 7.17 \\
\hline
\end{tabular}


This showed that when less amount of water was applied under at CRI stage $\left(\mathrm{I}_{1}\right)$ and 0.6 IW/CPE ratio $\left(\mathrm{I}_{2}\right)$, deeper layers were subjected to more moisture depletion since moisture stress under such conditions promotes extensive root growth in lower layers. These results confirm with the findings of Parihar and Tripathi (1990),

\section{Consumptive use of water}

The consumptive use of water evident that the increasing moisture regimes from CRI stage $\left(\mathrm{I}_{1}\right)$ and $0.6 \mathrm{IW} / \mathrm{CPE}\left(\mathrm{I}_{2}\right)$ to $1.2 \mathrm{IW} / \mathrm{CPE}$ ratio $\left(\mathrm{I}_{5}\right)$ increased the consumptive use of water. At moisture regime of $1.2 \mathrm{IW} / \mathrm{CPE}$ ratio $\left(\mathrm{I}_{5}\right)$ was observed $(56.95 \mathrm{~cm})$ which was highest over CRI $\left(\mathrm{I}_{1}\right)$ and $0.6\left(\mathrm{I}_{2}\right), 0.8\left(\mathrm{I}_{3}\right), \quad 1.0$ IW/CPE ratio $\left(\mathrm{I}_{4}\right)$.

While lower consumptive of water $(13.42 \mathrm{~cm})$ recorded under moisture regime at CRI stage $\left(\mathrm{I}_{1}\right)$. This was mainly due to greater loss of applied water through evapo transpiration because of more availability of water resulted in to better plant growth.

In contrast, the lowest consumptive use of water $(13.42 \mathrm{~cm})$ was computed under moisture regime of at CRI stage $\left(\mathrm{I}_{1}\right)$ due to combination of lower surface evaporation and reduced transpiration under less soil moisture availability. These finding are well supported by Parihar and Tiwari (2003.

\section{Water use efficiency (WUE)}

Water use efficiency as influenced by various moisture regimes has been given in table 2 . The water use efficiency decreased with increasing level of moisture regimes. The maximum water use efficiency $\left(166.6 \mathrm{~kg} \mathrm{ha}^{-}\right.$ ${ }^{1} \mathrm{~mm}^{-1}$ ) was obtained under moisture regime at CRI stage $\left(\mathrm{I}_{1}\right)$ followed by irrigation at 0.6 IW/CPE $\left(\mathrm{I}_{2}\right)$. The lowest water use efficiency recorded $\left(71.7 \mathrm{~kg} \mathrm{ha}^{-1} \mathrm{~cm}^{-1}\right)$ under moisture regime at 1.2 IW/CPE ratio $\left(\mathrm{I}_{5}\right)$. These might be due to fact that as grain yield did not increased proportionately to that of consumptive use. Similar research findings were also reported by Deo et al., (2017), Khan et al., (2007), Chavan and Pawar (1988), Khola et al., (1989), Parihar and Tripathi (1990), Rajann et al., (2016) and Salunkhe et al., (2015).

On the basis of the present investigation it may be concluded that the mmoisture regime 1.0 IW/CPE ratio (5-6 irrigations) was found suitable for achieving higher root growth, yield, improving in soil properties and enhancing the consumptive water use of wheat.

\section{References}

Anonymous (2016). In Progress report All India Coordinated Wheat \& Barley Improvement Project, ICAR-I I W \& B R, Karnal, pp 02.

Chouhan, B.S.; Kaushik, M.K. Napelia, V. Solanki, N.S. Singh, B.; Devra, N.S., Kumawat, P. and Kumar, A. (2017). Effect of sowing methods, scheduling of irrigation based on IW/CPE ratio and chemical weed control on plant height, dry matter accumulation and yield of wheat. Journal of Pharmacognosy and Photochemistry, 6 (3): 169-172.

Dangar, D.M., Dwivedi, D.K. and Mashru, H.H. (2017). Effect of irrigation regime and lateral spacing on drip irrigated wheat. International Journal of Agricultural Science and Research, Vol. 7 (1): 417-422.

Dastane, N. G. (1972). A practical manual for water use research in agriculture, Navbharat Prakashans, Poona-4, India

Deo, K.; Mishra, S.R.; Singh, A.K., Mishra, A.N., and Singh, S. (2017). Water requirement of wheat crop for optimum production using CROPWAT model. 
Journal of Medicinal Plants Studie, 5(3): 338-342.

Jeckson, M.L. (1973) Soil chemical analysis. Prentice hall of India Pvt. Ltd, New Delhi

Jat, M. L.; Shivran, A. C.; Puniya, M. M.; Boori, P. K.; Ola, B. L. and Verma, H. P. (2015). Effect of drip irrigation scheduling on growth and seed production of fennel (Foeniculum vulgar Mill.) under semi-arid agroclimatic condition. International J. Seed Spices 5(2):67-73.

Kanwar, J. S. and Chopra, S. L. (1991) Analytical Agricultural Chemistry, Kalyani Publishers, New Delhi

Kaur, J. and Mahal, S.S. (2016).Influence of paddy straw mulch on crop productivity and economics of bed and flat sown wheat (Triticum aestivum L.) under different irrigation schedules. Journal of Environmental Biology, Vol.38 243250.

Kumar, A.; Kumar, S.; Singh, A.K.; Kumar,D.; Harikesh.; Gopal, T.; Pandey, D. and Pandey, V.K. (2018).Effect of Moisture Regime and Nutrient Management System on Yield and Economics of Wheat (Triticum aestivum L.). Int. J. Curr. Microbiol. App. Sci, 7(2):59-66.

Nayak, M.K.; Patel, H.R., Prakash, V. and Kumar, A. (2015). Influence of Irrigation Scheduling on Crop Growth Yield and Quality of Wheat. Journal of Agri. Search, 2(1): 65-68.

Olsen, S.R.; Cole, C.V.; Watanable, F.S. and Dean, L.A. (1956) Estimation of available phosphorus in soil by extraction with sodium bicarbonate. USDA, Cric 930: 19-23 (C.F. methods of soil analysis. Ed. Black: C.A. Agronomy, No. 9 American Society of Agronomy Inc. Madison, Wisconsin, 1044-1046
Parihar, S. S., K. L. Sandhu and Sandhu, B. S. (1976). Comparison of irrigation schedule based on pan evaporation and growth stages in wheat. Indian Journal of Agronomy, 68: 650-653

Parihar, S. S. and Tiwari, R. B. (2003). Effect of nitrogen level on yield, nutrient uptake and water use of late sown wheat (Triticum aestivum L.), Indian Journal of Agronomy, 48(2):103-107

Rahman, M.A., Karim, A.J.; M.S., Haque; M.M. and Eqashira, K. (2000). Effect of irrigation and nitrogen fertilization on plant growth and root characteristics of wheat on a clay terrace soil of Bangladesh. J. Faculty of Agric,45 (1): 301-308.

Singh, J; Mahal, S. S. and Manhas, S. S. (2012). Effect of Agronomic Practices on Growth, Grain yield, Malt yield losses of Barley (Hordeum vulgare L.). Journal of Agricultural Physics, 12(1):74-83

Subbiah, B.V. and Asiza, C.L. (1956). A rapid procedure for the estimation of available $\mathrm{N}$ in soil. Current Sci. 25: 259-260

Tripathi, S. and Bastia, D.K. (2012). Irrigation and nutrient management for yields augmentation of summer sesame (Sesamum indicum L.). J. Crop and Weed, 8 (2): 53-57.

Vision, (2020).Perspective Plan, Directorate of Wheat Research, Karnal, pp: 36-41.

Walkley, A. and Black, A.I. (1934). Soil Sci. 37 29-38. Old piper, S.S. Soil and plant analysis, Nans Publishers Bombay

Yadav, S. and Singh, B.N. (2014). Effect of irrigation schedules and planting methods on yield, attributes and economics of green gram (Phaseolus radiata L.) under rice-wheat-green gram cropping system. Plant Archives, 14(1): 521-523. 


\section{How to cite this article:}

Sudhir Pal, Suresh Kumar, Pravesh Kumar, Anshul Singh and Hemant Kumar Gangwar. 2020. Effect of Moisture Regime on IW/CPE Ratio on Soil Properties, Yield and Water use Efficiency of Wheat Crop (Triticum aestivum L.). Int.J.Curr.Microbiol.App.Sci. 9(03): 24992506. doi: https://doi.org/10.20546/ijcmas.2020.903.286 